\title{
PENGARUH PENGUMUMAN PERUBAHAN PERINGKAT OBLIGASI TERHADAP PERILAKU INVESTOR PADA PERUSAHAAN ASING DAN DOMESTIK
}

\author{
Irdha Yusra \\ Sekolah Tinggi Ilmu Ekonomi "KBP" \\ irdhayusra@gmail.com
}

\begin{abstract}
The objective of this research is to examine differences behavior investors to bond rating changes in foreign and domestic companies. The event date is the time when PT Pefindo as a rating agency in Indonesia announce the changes of bond rating during 2002-2011. Event study method is used to analyze investor reaction to bond rating changes announcement. The samples are taken by purposive sampling method and the results are 89 observation, 51 upgrade and 7 downgrade for foreign companies, 15 upgrade and 16 downgrade for domestic companies.

Market model used to calculate whether there is any abnormal return. Event windows are 21 days which 10 days before the rating announcement, the day of rating announcement, and 10 days after the rating announcement. The variables is average abnormal return. Generally, the were positive abnormal return at bond rating upgrade announcement and there were negative abnormal return at bond rating downgrade announcement. The result is Indonesian Capital Market, especially Indonesian Stock Exchange significantly react to bond rating upgrade and downgrade, for both categories of foreign and domestic companies. This results indicates that investors react positively to the announcement of the change of bond rating companies foreign and domestic. This research also find different response from investors, where the reaction of investors to changes of bond rating from domestic companies higher than to changes of bond rating from foreign companies.
\end{abstract}

Keyword: Bond rating, event study, market model

\section{PENDAHULUAN}

Pasar modal pada dasarnya bertujuan untuk menjembatani aliran dana dari pihak yang memiliki dana (investor) dengan pihak perusahaan yang memerlukan dana (untuk ekspansi usaha ataupun untuk memperbaiki struktur modal perusahaan), baik berupa saham

Oleh karena itu, pasar modal memiliki peran penting dalam kegiatan ekonomi. Ika dan Singgih (1996) telah melakukan penelitian maupun dalam bentuk obligasi. Tandelilin (2010:26) mendefinisikan pasar modal sebagai pasar untuk memperjual-belikan sekuritas yang umumnya memiliki umur lebih dari satu tahun, seperti saham dan obligasi.

terkait dengan peranan pasar modal Indonesia dalam memenuhi target investasi. Mereka menemukan bahwa pasar modal telah menjadi salah satu 
sumber kemajuan ekonomi dan memiliki prospek yang baik bagi investor.

Berdasarkan data statistik pasar modal Indonesia yang terdapat di Bapepam LK, pasar modal Indonesia terus menunjukkan trend yang meningkat. Peningkatan ini dapat dilihat berdasarkan pergerakan Indeks Harga Saham Gabungan (IHSG) yang meningkat hingga bulan Agustus pada tahun 2011. Hal ini menunjukkan terjadinya peningkatan permodalan emiten yang ditanamkan oleh para investor, khususnya investor asing. Meskipun IHSG sempat turun hingga bulan Oktober, tetapi setelah itu justru mengalami peningkatan yang signifikan. Hal ini mengindikasikan investor asing di Indonesia terus masuk dari perdagangan saham di Bursa Efek Indonesia.

IHSG $\begin{array}{rr}\text { Secara umum, } & \text { pergerakan } \\ \text { memang } & \text { hanya }\end{array}$ menggambarkan pergerakan secara agregat. Sehingga sulit dideteksi apakah peningkatan ini disebabkan oleh dominasi investor asing atau bahkan sebaliknya, peningkatan tersebut justru disebabkan oleh dominasi investor domestik. Namun, berdasarkan data yang diperoleh, argumen tentang peningkatan yang disebabkan oleh peran investor asing didukung oleh data yang dimiliki Kustodian Sentral Efek Indonesia (KSEI), investor asing masih mendominasi Kepemilikan saham yang tersimpan di KSEI periode 31 Desember 2011. Investor asing

Ketika informasi baru berupa pengumuman perubahan peringkat obligasi masuk dan relevan bagi perubahan harga, maka harga ekuilibrium tersebut akan bergerak memiliki lebih dari 50\% efek yang tersimpan di KSEI, yaitu sebesar $55.35 \%$ atau lebih besar dibandingkan efek yang dimiliki oleh investor lokal.

Praktis sejak berdirinya pasar modal Indonesia, konstribusi investor asing selalu lebih besar, dengan kata lain mereka yang lebih banyak menikmati keuntungan akibat pertumbuhan ekonomi tersebut. Keberadaan investor asing tersebut di satu sisi memang memberikan pengaruh positif karena membuat bursa saham lebih likuid. Di sisi lain, Errunza (1986) juga menjelaskan bahwa investasi portofolio oleh investor asing dapat memberikan tiga pengaruh positif, yaitu (1) mengembangkan pasar modal di negara tujuan (development effect), (2) meningkatkan sumber pendanaan dari luar (resource effect), dan (3) meningkatkan nilai saham yang pada akhirnya meningkatkan nilai portofolio oleh investor lokal (welfare effect). Dominasi kepemilikan saham oleh investor asing membuat kinerja pasar modal bisa sangat fluktuatif karena ada potensi penarikan dana setiap saat sehingga saat itulah peran investor lokal diperlukan. Ketika investor asing menarik portofolionya, maka investor lokal pun dapat menggantikan posisinya tersebut.

Secara teoritis dinyatakan bahwa informasi yang relevan dapat menimbulkan reaksi pasar yang dapat tercermin dari harga atau return.

kembali sesuai dengan hukum pasar hingga tercapai ekuilibrium baru. Jika harga tersebut bergerak secara cepat (quickly) dan akurat, maka dapat dikatakan pasar tersebut 
efisien. Jadi, suatu pasar akan efisien secara informasi (informationally efficient market) jika harga yang telah ada merefleksikan secara penuh (fully reflect) semua informasi yang relevan.

Ketepatan pelaku pasar dalam
bereaksi terhadap suatu
pengumuman akan terlihat dari
ketepatannya dalam mengambil
keputusan. Hal ini penting, karena
bila terjadi kesalahan dalam
merespon informasi maka akan
berakibat terhadap tingkat
keuntungan yang diperoleh. Pelaku
pasar perlu menginterpretasikan
informasi tersebut secara tepat,
apakah sebagai kabar baik (good
news) atau kabar buruk (bad news),
sehingga diperlukan analisis yang
lebih mendalam terhadap seberapa
besar dampak dari informasi tersebut
terhadap harga.

Informasi lengkap tentang kondisi perusahaan tersebut dimiliki oleh para agen perusahaan seperti direksi dan manager perusahaan. Informasi ini tidak akan keluar ke publik begitu saja karena agen tersebut harus memenuhi regulasi yang ada dalam menyampaikan informasi tersebut ke publik. Informasi tersebut selalu ditahan perusahaan dan Menginformasikan pada waktu yang tepat. Sehingga, investor akan memiliki informasi yang kurang lengkap dibandingkan agen perusahaan. Gap antara informasi yang diperoleh agen dan investor inilah yang dikenal dengan asymmeric information.

Penelitian ini menyajikan konstribusi yang cukup dominan dibandingkan dengan penelitian sebelumnya (Goh \& Louis, 1993; Dichev, 1998; Bhattacharya dkk,
Dalam penelitian ini, perusahaan dikelompokkan menjadi 2 (dua) jenis, yaitu perusahaan asing dan perusahaan domestik. Pilihan pembedaan atas kedua tipe perusahaan ini didasarkan pada besarnya proporsi kepemilikan mereka dalam perusahaan (Chandra, 2010). Selain itu, pilihan ini juga didasarkan pada nilai abnormal return yang diperoleh oleh masingmasing perusahaan tersebut. Dengan kata lain, sekalipun masing-masing perusahaan mengalami perubahan peringkat obligasi yang sama (upgrade atau downgrade), ternyata nilai abnormal return yang diperoleh berbeda (positif dan negatif). Nilai abnormal return tersebut mengindikasikan bahwa kalau perusahaan dikategorikan dalam kelompok perusahaan asing dan domestik, maka belum dapat diketahui apakah perubahan peringkat obligasi direaksi sama oleh investor.

Selain itu, yang akan dikaji lebih lanjut adalah apakah benar sebuah pengumuman direaksi oleh investor sebagai suatu kejadian, kalau perusahaan tersebut dikategorikan sebagai perusahaan asing dan perusahaan domestik. Apabila direaksi, reaksi investor manakah yang lebih tinggi, apakah reaksi terhadap perusahaan asing yang mengalami perubahan peringkat obligasi atau reaksi terhadap perusahaan domestik yang mengalami perubahan peringkat obligasi.

2000; Gropp \& Anthony, 2001; Campbell, Hilscher, \& Szilagyi, 2005; Ariyanti, 2008; Suwiryo, 2009) yakni dalam hal kemampuan untuk menyajikan bukti empiris 
reaksi abnormal atas return yang dipicu oleh aksi investor asing yang telah bereaksi terlebih dahulu ketimbang investor domestik.

\section{KERANGKA TEORI DAN HIPOTESIS}

\section{Asimetri informasi} (asymmetric information) merupakan informasi privat yang hanya dimiliki oleh investor-investor yang mendapat informasi saja (informed investor). Hanafi (2004) mengatakan bahwa asymmetric information muncul ketika manajer lebih mengetahui informasi internal dan prospek perusahaan dimasa yang akan datang dibandingkan pemegang saham dan stakeholder lainnya. Sedangkan Chae (2005), dan Manurung (2012) juga menjelaskan bahwa asimetri informasi terjadi ketika adanya perbedaaan informasi antara agen perusahaan dan investor.

Menurut Sartono (1996)
dalam Raharja \& Maylia (2008),
asimetri informasi dapat terjadi di
antara dua kondisi ekstrem, yaitu
perbedaan informasi yang kecil
sehingga tidak mempengaruhi
manajemen, atau perbedaan yang
sangat signifikan sehingga dapat
berpengaruh terhadap manajemen
dan harga saham. Implikasinya
adalah pengumuman perusahaan
untuk melakukan peringkat obligasi
akan direspon oleh pasar sebagai
suatu sinyal yang menyampaikan
adanya informasi baru yang
dikeluarkan oleh pihak manajemen
yang selanjutnya akan

Adam Smith, dalam bukunya The Money Game yang dikutip oleh Daniri (2008) mengatakan bahwa perilaku investor itu didorong oleh dua hal, yaitu ketakutan (fear) dan keserakahan (greed). Perilaku yang mempengaruhi harga saham aktivitas perdagangan.

$$
\text { Investor pasar keuangan }
$$
adalah investor yang beragam. Keberagaman dikonstribusikan oleh beberapa aspek, yaitu motivasi investasi, daya beli (purchasing power) terhadap saham, pengalaman dan tingkat pengetahuan dan kematangan investasi serta perilaku investasi. Keberagaman ini akan membuat perbedaan tingkat keyakinan (confidence) dan harapan (expectation) atas return dan risk atas kegiatan investasi. Adanya keberagaman inilah yang sesungguhnya mendorong terjadinya transaksi.

Keyakinan dan harapan inilah yang melahirkan perilaku investasi yang beragam. Dorsey (2003) menyatakan "human behaviour is the key determinants of the market". Argumen ini menjelaskan bahwa kunci pergerakan harga saham bukanlah faktor fundamental dan teknikal, melainkan perilaku investor. Perilaku itu dibentuk oleh level confidence (keyakinan) dan expectation (harapan) investor. Disaat pasar sedang bergerak naik (bullish), keyakinan dan harapan investor cukup tinggi, melebihi hitung-hitungan fundamental. Sebaliknya, ketika pasar melemah (bearish), keyakinan dan harapan pasar teramat rendah meskipun faktor fundamental cukup menjanjikan.

didorong oleh kedua hal ini relatif akan mengacaukan bangunan hipotesis pasar efisien yang telah banyak diyakini oleh peneliti ilmu keuangan. 
Pasar saham dikatakan efisien jika penyesuaian harga terjadi secara cepat atas kedatangan informasi baru dan harga saham merefleksikan semua informasi relevan yang tersedia (Scott, 2003). Tandelilin (2010:219) juga mendefinisikan bahwa pasar modal yang efisien adalah dimana harga semua sekuritas yang diperdagangkan telah mencerminkan semua informasi yang tersedia. Dalam hal ini, informasi yang tersedia bisa meliputi semua informasi yang tersedia baik informasi dimasa lalu dan informasi saat ini.

$\begin{array}{lrr}\text { Fama } & \text { (1970) } \\ \text { Tandelilin } & (2010: 223)\end{array}$
mengklasifikasikan bentuk pasar yang efisien ke dalam tiga efficient market hypothesis (EMH), yaitu weak-form efficient, semistrong-form efficient dan strong-form efficient. Pasar weak-form efficient jika harga sekuritas merefleksikan secara penuh informasi harga dan volume perdagangan saham masa lalu (biasanya tersedia secara publik. Pasar semistrong-form efficient jika harga sekuritas merefleksi secara penuh semua informasi yang tersedia secara publik termasuk data laporan keuangan. Sedangkan pasar strongform efficient jika harga sekuritas merefleksi secara penuh semua informasi termasuk informasi privat atau dalam (inside information) yang tidak dipublikasikan atau off-the records (Scott, 2003).

Peringkat obligasi merupakan suatu penilaian yang terstandardisasi terhadap kemampuan suatu negara atau perusahaan dalam membayar hutang-hutangnya (Rudianto, 2011). Peringkat obligasi yang diberikan oleh lembaga pemeringkat memberikan gambaran tentang kredibilitas (creditworthiness) dan akan mempengaruhi penjualan obligasi tersebut (Fabozzi, 2000). Lebih lanjut menurut Fabozzi (2000) resiko gagal bayar (default risk) adalah resiko muncul karena penerbit obligasi tidak mampu membayar bunga dan pokok obligasi pada waktu yang ditetapkan sesuai pada saat obligasi tersebut diterbitkan.

Lembaga pemeringkat efek adalah lembaga yang sengaja dibentuk untuk melakukan fungsi pemeringkatan terhadap efek-efek yang bersifat utang yang diterbitkan oleh perusahaan. Ia melakukan penilaian terhadap kinerja setiap perusahaan yang akan menerbitkan surat utang. Menurut Karyani \&Adler (2006) fungsi utama lembaga pemeringkat adalah untuk memberikan rating yang obyektif, independen, dan kredibel terhadap risiko kredit dari sekuritas pinjaman (debt) yang diterbitkan secara umum melalui kegiatan pemeringkatan.

Manfaat umum dari proses pemeringkatan adalah : (1) Keterbukaan sistem informasi pasar; (2) Efisiensi biaya; (3) Menentukan besarnya coupon; (4) Memberikan informasi yang obyektif dan independen yang menggambarkan kondisi pasar obligasi dan kondisi ekonomi pada umumnya (Karyani \&Adler, 2006).

Secara garis besar, lembaga pemeringkat membuat skala peringkat utang dengan formasi yang tidak jauh berbeda satu sama lain. Menurut Hanafi (2004) ada dua tahap yang biasanya dilakukan dalam proses pemeringkatan obligasi yaitu: (1) Melakukan review internal terhadap perusahaan yang mengeluarkan instrumen utang; (2) 
Hasil dari review internal tersebut akan direkomendasikan kepada komite rating yang akan menentukan peringkat obligasi perusahaan tersebut.

Banyak penelitian yang sudah dilakukan terkait dengan reaksi investor terhadap pengumuman perubahan peringkat obligasi. Namun, dengan mengambil kondisi pasar modal Indonesia tidak ditemukan penelitian yang mencoba untuk menguji perilaku investor terhadap pengumuman perubahan peringkat obligasi perusahaan asing maupun domestik. Kelompok perusahaan asing dan domestik didasarkan pada jumlah kepemilikan investor dalam sebuah perusahaan. Jika suatu perusahaan lebih didominasi oleh kepemilikan investor asing, maka dalam penelitian ini perusahaan tersebut dikategorikan sebagai perusahaan asing. Sebaliknya, jika suatu perusahaan lebih didominasi oleh kepemilikan investor domestik, maka perusahaan tersebut dikategorikan sebagai perusahaan domestik. Oleh sebab itu, penelitian ini mencoba menggali lebih jauh mengenai perilaku investor dengan adanya pengumuman perubahan peringkat obligasi perusahaan-perusahaan tersebut. Kemungkinan para investor akan memiliki perilaku yang berbeda.

Bhattacharya, dkk (2000) menjelaskan mengapa suatu pengumuman berita baru perusahaan tidaklah secara nyata sebagai suatu kejadian. Alasan pertama, adanya kemungkinan pasar modal dalam bentuk pasar modal yang tidak efisien yang mengimplikasikan bahwa harga saham tidak terasosiasi dengan nilai perusahaan. Kedua, adanya pendukung kemungkinan bahwa pengumuman peringkat obligasi perusahaan tidak menyajikan nilai pautan. Artinya, pengumuman peringkat obligasi perusahaan tidak mampu menstimulasi terhadap respon para pelaku pasar. Ketiga, adanya kemungkinan kombinasi dari kedua alasan, yakni dalam bentuk yang sekalipun pasar modal dalam bentuk efisien dan berita baru perusahaan memiliki nilai-pautan, tetapi pengumuman peringkat obligasi perusahaan tersebut telah terantisipasi secara lengkap dalam periode sebelumnya sehingga pengumuman tidak lagi mengejutkan. Hasil penelitian Bhattacharya, menemukan bahwa return dalam event windows yang diterapkan secara konvensional (satu hari sebelum dan dua hari setelah) firm-specific news announcements dipublikasikan tidak terjadi keabnormalan. Penelitiannya juga menyajikan bukti empiris tentang reaksi abnormal return yang dipicu oleh aksi investor domestik yang telah bereaksi terlebih dahulu ketimbang investor asing.

Seasholes (2000) juga melakukan penelitian terkait dengan pengujian pasar modal Taiwan, tetapi dengan pengumuman yang berbeda (yaitu laba). Dia melihat pada pembelian bersih asing sebelum adanya kejutan laba positif dan negatif. Hasil penelitiannya menunjukkan bahwa orang asing cenderung membeli saham sebelum adanya kejutan laba positif dan menjual saham sebelum adanya kejutan laba negatif. Return harian portofolio asing yang mengalami kemunduran secara konstan pada return pasar diperkirakan signifikan 
positif secara statistik, ia menunjukkan bahwa orang asing mendapatkan risiko pasar di atas adjusted return. Hal ini tentu saja mengasumsikan bahwa portopolio pasar yang relevan untuk orang asing adalah pasar Taiwan. Dia menafsirkan kekuatan prediktif dari informasi yang mengalir sebagai keuntungan pada pihak investor asing.

\begin{tabular}{lccc}
\multicolumn{1}{c}{ Kang } & \& & Stulz & $(1997)$ \\
melakukan & penelitian & dengan \\
menggunakan & data & tentang
\end{tabular}
kepemilikan saham asing di Jepang antara tahun 1975 sampai 1991 untuk meneliti faktor-faktor penentu home bias dalam portofolio kepemilikan. Mereka menemukan bahwa investor asing memegang portofolio pasar domestik atau portofolio yang lebih tinggi. Dari penjelasan dan hasil penelitian di atas, bisa dirumuskan hipotesis sebagai berikut:
$\mathbf{H}_{1 \mathbf{a}}$ : Investor bereaksi positif terhadap pengumuman peningkatan peringkat obligasi perusahaan asing.

$\mathbf{H}_{1 \mathrm{~b}}$ : Investor bereaksi negatif terhadap pengumuman penurunan peringkat obligasi perusahaan asing.

\section{Goh \& Louis}

melakukan penelitian tentang reaksi return saham terhadap perubahan peringkat obligasi yang di umumkan oleh Moody's selama periode 19841986, hasil penelitiannya menunjukkan bahwa adanya pengaruh negatif yang signifikan dari penurunan peringkat obligasi (downgrades) terhadap return saham. Peneliti berpendapat bahwa (1) beberapa perubahan rating telah diantisipasi oleh partisipan (investor) terlebih dahulu, (2) penurunan peringkat (downgrades) terjadi karena adanya pemindahan kekayaan dari bondholders ke stockholders, yang seharusnya menjadi berita baik (good news) bagi stockholders.

Gropp \& Anthony (2001) menyatakan bahwa penelitian yang terkait dengan perubahan pengumuman peringkat obligasi dilakukan oleh lembaga pemeringkat internasional yang berfokus pada sampel Bank Eropa. Mereka menemukan bahwa pengumuman peringkat obligasi tidak memiliki dampak pada harga obligasi. Tetapi untuk harga ekuitas, perubahan peringkat memiliki pengaruh kuat terhadap harga saham. Secara keseluruhan, mereka mengemukakan bahwa pemeringkat obligasi mempunyai peran yang sangat berguna dalam meringkas dan memperoleh informasi non-publik di bank, setidaknya informasi yang berguna bagi stockholders. Hasil penelitian mereka menunjukkan bahwa risiko kredit (obligasi) berhubungan negatif dengan return saham.

Penelitian yang dilakukan oleh Kliger \& Oded (2000) menemukan bahwa informasi mengenai peringkat obligasi tidak berpengaruh terhadap nilai perusahaan (firm value), tetapi peningkatan (penurunan) nilai utang (debt value) dan turun (naik) nya nilai ekuitas (equity value) ketika Moody's mengumumkan baik (jelek) nya peringkat obligasi. Peneliti juga menemukan bahwa ketika Moody's mengumumkan kenaikan peringkat obligasi, volatilitas yang tercermin dalam harga saham menjadi menurun. Sebaliknya, ketika Moody's mengumumkan penurunan 
peringkat obligasi, volatilitas harga saham menjadi meningkat. Dari beberapa penelitian di atas, disimpulkan bahwa pengumuman perubahan peringkat obligasi memiliki pengaruh yang berbedabeda terhadap reaksi pasar.

Penelitian Dvorak (2005) menunjukkan bahwa investor domestik memperoleh keuntungan yang lebih tinggi dibandingkan dengan investor asing. Hal ini dikarenakan kedekatan informasi, investor domestik memiliki informasi yang lebih dibandingkan dengan investor asing. Konstribusi investor asing dalam perdagangan justru negatif bersamaan dengan konstribusi positif investor domestik (Harsono, 2003).

Dalam kondisi pasar modal Indonesia, Zuhrotun (2005) melakukan penelitian tentang pengaruh pengumuman peringkat terhadap kinerja obligasi selama periode 2000 sampai dengan 2004. Sampel penelitiannya berjumlah 76 obligasi, yang terdiri dari 17 upgrade, 20 downgrade, dan 39 stabil. Sedangkan obligasi dari perusahaan kecil berjumlah 25 obligasi, dan dari perusahaan besar berjumlah 30 obligasi. Hasil penelitiannya menyimpulkan bahwa hanya downgrade yang memiliki kandungan informasi. Dia juga menyatakan bahwa kabar buruk (bad news) lebih direspon oleh investor.

Ariyanti (2008) juga
melakukan penelitian tentang
pengaruh pengumuman perubahan
peringkat obligasi (upgrades dan
downgrades) terhadap return saham.
Event date yang dipilih adalah
tanggal pengumuman perubahan
peringkat obligasi yang dikeluarkan

oleh PT.PEFINDO sebagai lembaga pemeringkat di Indonesia. Hasil penelitiannya menunjukkan bahwa terdapat abnormal return negatif di sekitar pengumuman downgrade obligasi dan abnormal return positif lemah atau bahkan tidak ada abnormal return positif di sekitar pengumuman upgrade obligasi. Dia menyimpulkan bahwa pasar modal Indonesia (khususnya Bursa Efek Indonesia) memiliki reaksi yang signifikan terhadap pengumuman upgrade dan tidak bereaksi terhadap pengumuman downgrade peringkat obligasi.

Penelitian Andriansyah (2002) justru menemukan hasil yang berbeda. Dia menemukan bahwa adanya abnormal return negatif pada saat pengumuman downgrade dan abnormal return positif pada saat pengumuman upgrade. Dia melakukan penelitian terhadap 71 observasi yang terdiri dari 57 downgrade, dan 14 upgrade selama periode September 1996 sampai dengan Mei 2001. Sehingga, dia menyimpulkan bahwa pasar modal Indonesia bereaksi positif terhadap pengumuman perubahan peringkat obligasi. Berdasarkan argumentasi di atas, bisa dirumuskan hipotesis sebagai berikut:
$\mathbf{H}_{2 \mathbf{a}}$ : Investor bereaksi positif terhadap pengumuman peningkatan peringkat obligasi perusahaan domestik.
$\mathbf{H}_{2 b}$ : Investor bereaksi negatif terhadap pengumuman penurunan peringkat obligasi perusahaan domestik.

$\begin{array}{llr}\text { Choe } & \text { \& Stulz } & \text { (2001) } \\ \text { melakukan } & \text { penelitian } & \text { dengan } \\ \text { menggunakan } & \text { data intraday } & \text { pasar }\end{array}$


modal di Korea. Penelitian mereka menunjukkan bahwa investor domestik memiliki lebih banyak informasi daripada investor. Temuan ini berbeda dengan penelitian Seasholes (2000) yang menyimpulkan bahwa perusahaan asing yang didominasi oleh investor asing memiliki informasi yang lebih baik tentang faktor-faktor fundamental yang berkaitan dengan ekuitas daripada perusahaan domestik yang didominasi investor domestik.

Froot \& Ramadorai (2001) juga melakukan penelitian terkait dengan perbedaan informasi yang dimiliki oleh tipe investor. Mereka menggunakan data dari 25 negara bagian di Amerika Serikat. Hasil penelitiannya menjelaskan bahwa informasi fundamental investor asing lebih baik dibandingkan investor lokal. Sedangkan Kang dan Stulz (1997) justru tidak menemukan perbedaan abnormal return antara investor asing dan domestik pada pasar modal Jepang.

Dalam penelitiannya Choe dkk (2001) membandingkan harga saham intraday antara investor domestik dengan investor asing. Mereka menemukan bahwa investor asing membeli lebih tinggi dan menjual lebih rendah harga saham daripada investor domestik. Keuntungan dari pendekatan ini adalah bahwa pendekatan ini tidak tergantung pada asset pricing model apapun, yaitu tidak perlu memperhitungkan risiko. Namun, membandingkan investor asing dan domestik hanya pada frekuensi intraday. Hal ini mencegah kemungkinan bahwa informasi asimetri antara investor asing dan domestik mungkin terjadi dalam jangka panjang. Selain itu, pendekatan mereka tidak dapat membedakan antara asimetri dan umpan balik positif perdagangan dipihak investor asing. Misalnya jika investor asing membeli setelah kenaikan harga, mereka membayar harga yang lebih tinggi, tetap tidak jelas apakah ini harus ditafsirkan sebagai suatu pendekatan dalam informasi atau gaya investasi.

Suwiryo (2009) menyatakan bahwa pengumuman tidaklah mesti direaksi sebagai suatu peristiwa apabila pelakunya dibedakan antara investor asing dan investor domestik. Dia menemukan bahwa adanya kebocoran informasi yang ditunjukkan oleh investor asing, hal ini mengidentifikasi adanya insider trading. Investor asing memiliki informasi khusus sebelum pengumuman dan memanfaatkan informasi tersebut pada perdagangan.

Dari beberapa penelitian di atas dapat disimpulkan bahwa adanya kemungkinan pengumuman perubahan peringkat obligasi direaksi atau tidak direaksi oleh pelaku pasar. Apabila perusahaan yang mengalami perubahan peringkat obligasi dikelompokkan sebagai perusahaan asing dan domestik, maka ada kemungkinan investor akan lebih bereaksi terhadap pengumuman perubahan peringkat obligasi perusahaan domestik dibandingkan terhadap pengumuman perubahan peringkat obligasi perusahaan asing. Alasannya adalah perusahaan asing (dalam hal ini adalah perusahaan yang sebagian atau seluruh sahamnya dimiliki oleh investor asing) memiliki tingkat pengetahuan dan pengalaman yang lebih tinggi dibandingkan dengan perusahaan domestik (dalam hal ini adalah perusahaan yang sebagian atau 
seluruh sahamnya dimiliki oleh investor domestik). Alasan lainnya adalah perusahaan asing memiliki informasi yang lebih lengkap dibandingkan dengan perusahaan domestik. Dengan demikian, hipotesis yang dapat disusun dalam penelitian ini adalah sebagai berikut:

$\mathbf{H}_{3}$ : Reaksi investor terhadap pengumuman peningkatan (penurunan) peringkat obligasi perusahaan domestik lebih tinggi dibandingkan pengumuman peningkatan (penurunan) peringkat obligasi perusahaan asing.

\section{METODOLOGI}

\section{Data dan Sampel}

Populasi dalam penelitian ini adalah saham-saham yang tergabung di Bursa Efek Indonesia dalam periode pengamatan tahun 2002 sampai dengan tahun 2011. Sampel penelitian yang digunakan diambil dengan menggunakan metode purposive sampling, kriteria dalam pemilihan sampel adalah (1) perusahaan yang mengalami perubahan peringkat obligasi (peningkatan atau penurunan) periode 2002-2011, (2) tersedianya data tanggal pengumuman peringkat obligasi dan kelengkapan data perdagangan, (3) perusahaan yang hanya melakukan kebijakan bond rating, sehingga jika pada saat atau bulan yang bersamaan perusahaan melakukan kebijakan corporate action seperti stocksplit, right issue, initial public offering (IPO), serta merger dan akuisisi yang dapat mempengaruhi harga saham, maka perusahaan tersebut keluar dari sampel, (4) perusahaan yang porsi kepemilikan sahamnya didominasi oleh investor asing dan domestik. Pengelompokan investor asing dan domestik didasarkan pada besarnya persentase kepemilikan mereka pada perusahaan.

Berdasarkan kriteria di atas, ditemukan sebanyak 171 sampel perusahaan yang mengalami perubahan peringkat obligasi selama periode pengamatan. Sampel perusahaan tersebut dibagi menjadi dua kelompok, yaitu kelompok perusahaan asing dan domestik. Sampel perusahaan untuk kelompok perusahaan asing terdiri dari 81 observasi yang mengalami kenaikan peringkat obligasi (upgrade), dan 22 observasi yang mengalami penurunan peringkat obligasi (downgrade). Sedangkan untuk kelompok perusahaan domestik terdiri dari 36 observasi yang mengalami kenaikan peringkat obligasi (upgrade), dan 32 observasi yang mengalami penurunan peringkat obligasi (downgrade). Data perubahan peringkat obligasi tersebut diperoleh dari dari Bloomberg yang diterbitkan oleh PT.PEFINDO.

Perusahaan yang melakukan kebijakan corporate action selain kebijakan peringkat obligasi sebanyak 14 observasi. Untuk kelompok perusahaan asing, ditemukan sebanyak 9 observasi (upgrade) dan 4 observasi (downgrade) yang melakukan kebijakan corporate action lainnya. Sedangkan untuk kelompok perusahaan domestik, hanya ditemukan 1 observasi (upgrade) yang melakukan kebijakan corporate action lainnya. Data kebijakan corporate action tersebut diperoleh berdasarkan penelitian pada www.ksei.co.id. 


\section{Metode Analisis Data}

Analisis data merupakan kegiatan mengolah data yang telah terkumpul kemudian dapat memberikan interprestasi pada hasilhasil tersebut.Periode pengamatan dalam penelitian ini dibagi menjadi dua periode yaitu periode peristiwa (event period) dan periode estimasi (estimation period). Untuk periode peristiwa (yang sering juga disebut periode jendela atau event windows) dilakukan selama 21 hari pengamatan, terdiri dari selama 10 hari sebelum pengumuman $\left(t_{-10}\right)$, satu hari pada saat pengumuman $\left(t_{0}\right)$, dan 10 hari setelah pengumuman $\left(t_{+10}\right)$. Sementara untuk periode estimasi ditentukan selama 100 hari, yaitu dari 11 hari sampai dengan 110 hari sebelum pengumuman $\left(t_{-110}\right.$ sampai $\left.t_{-11}\right)$.

Untuk menguji reaksi investor terhadap pengumuman perubahan peringkat obligasi dapat dijelaskan sebagai berikut:

1. Menghitung actual return

$R_{i t}=\frac{P_{i t}-P_{i t-1}}{P_{i t-1}}$

Dimana $R_{i t}$ adalah actual return saham i pada hari t, $P_{i t}$ adalah harga saham i pada hari t, dan $P_{i t-1}$ adalah harga saham i pada hari $\mathrm{t}-1$.

2. Menghitung return pasar

$R_{m t}=\frac{I H S G_{t}-I H S G_{t-1}}{I H S G_{t-1}}$

Dimana $R_{m t}$ adalah return pasar saham pada hari $t$, $I H S G_{t}$ adalah indeks harga saham gabungan harian pada hari $\mathrm{t}$, dan $I H S G_{t-1}$ adalah indeks harga saham gabungan harian pada hari $\mathrm{t}-1$.

BEI merupakan pasar modal yang tipis dimana perdagangannya jarang terjadi, hal ini merupakan ciri dari pasar modal yang sedang berkembang (emerging market). Pasar modal yang tipis ini akan menyebabkan ketidaksinkronan antara return saham dengan indeks pasar (nonsynchronous trading), sehingga ketidaksinkronan ini akan menyebabkan perhitungan beta menjadi bias. Jika beta yang bias ini dijadikan dasar untuk menganalisis maka dikhawatirkan hasilnya pun akan bias (Bartholdy \& Riding, 1994; Tandelilin \&Wayan, 2001). Untuk itu dalam penelitian ini akan dilakukan koreksi bias pada beta sebelum digunakan untuk memprediksi return.

Berbagai metode koreksi estimasi beta untuk menghilangkan bias beta saham pernah dikemukakan antara lain oleh Scholes \& William (1977), Dimson (1979), serta Fowler \& Rorke (1983). Namun dalam penelitian ini, metode koreksi yang digunakan adalah metode Fowler \& Rorke dengan tiga periode mundur (lag time) dan tiga periode maju (lead time). Metode koreksi beta ini dipilih karena merupakan metode koreksi bias beta yang terbukti secara empiris paling mampu mengurangi bias beta di BEI. 
3. Menghitung expected return saham individual menggunakan market model, yaitu return historis saham yang diregresi dengan return historis suatu proksi portofolio pasar (Tandelilin, 2010). Indeks pasar yang digunakan sebagai proksi dalam penelitian ini adalah Indeks Harga Saham Gabungan (IHSG). Penerapan model regresi sederhana digunakan untuk mengestimasi model pasar. Adapun persamaan yang digunakan adalah sebagai berikut:

$$
E R_{i t}=\alpha_{0}+\beta_{1} R_{m t}+e_{i t}
$$

Dimana $E R_{i t}$ adalah expected return saham i pada hari t, $R_{m t}$ adalah return pasar yang diindikasikan oleh IHSG (composite index). $\alpha$ dan $\beta$ diperoleh dari hasil regresi time series antara return saham $\left(R_{i t}\right)$ dan return pasar $\left(R_{m t}\right)$ dalam periode estimasi, $t_{-110}$ sampai $t_{-11}$.

4. Menghitung return tak normal (abnormal return) saham individual menggunakan persamaan sebagai berikut:

$A R_{i t}=R_{i t}-E\left(R_{i t}\right)$

Dimana $A R_{i t}$ adalah return tak normal saham i pada hari $\mathrm{t}, R_{\text {it }}$ adalah return saham $\mathrm{i}$ pada hari t, dan $E\left(R_{i t}\right)$ adalah expected return saham i pada hari t.
5. Menghitung return tak normal rata-rata (mean abnormal return) untuk setiap interval waktu dalam periode peristiwa dengan menggunakan persamaan sebagai berikut:

$A A R_{t}=\frac{\sum_{i=1}^{n} A R_{i t}}{k}$

Dimana $A A R_{t}$ adalah return tak normal rata-rata pada waktu ke $\mathrm{t}$, dan $\mathrm{k}$ adalah jumlah sekuritas.

6. Menguji signifikansi abnormal return. Pengujian ini dilakukan untuk mengetahui apakah average abnormal return (AAR) berbeda dari 0 (nol). Pengujian dilakukan dengan uji $\mathrm{t}$ dengan rumus sebagai berikut:

$S A R=\frac{\overline{A R}}{K S E(\overline{A R})}$

Dimana $S A R$ adalah return tak normal yang telah distandarisasi untuk setiap sekuritas, sedangkan KSE adalah kesalahan standar estimasi yang dihitung dengan cara menghitung deviasi standar return setiap sekuritas selama periode estimasi, yaitu dengan menggunakan rumus sebagai berikut:

$K S E_{i}=\sqrt{\frac{\sum_{j=i}^{t-n}\left(R_{i j}-\bar{R}_{i}\right)^{2}}{T-n-2}}$

Dimana $K S E_{i}$ adalah kesalahan standar estimasi 
sekuritas ke-i, $R_{i j}$ adalah return aktual sekuritas ke-i untuk hari ke-j dalam periode estimasi, $\bar{R}_{i}$ return rata-rata aritmatik sekuritas ke-i selama periode estimasi, dan $T-n-2$ adalah jumlah hari atau interval waktu selama periode estimasi dikurangi 2 .

7. Menguji hipotesis pertama (H1) dan kedua (H2), yaitu dengan menentukan nilai $\mathrm{t}$ hitung kolektif yaitu dengan cara menjumlahkan ARS dan dibagi dengan akar $\mathrm{k}$ (jumlah sampel) atau dengan menggunakan rumus sebagai berikut:

thitung $=\frac{\sum S A R}{\sqrt{k}}$

Pengujian statistik bereaksi atau tidaknya investor terhadap pengumuman perubahan peringkat obligasi dilakukan dengan cara melihat signifikansi return tidak normal (abnormal return)yang ada diperiode jendela $(-10,+10)$. Signifikansi yang dimaksud adalah bahwa abnormal return tersebut secara statistik signifikan tidak sama dengan nol (positif untuk kabar baik dan negatif untuk kabar buruk). Pengujian-t ( $t$-test) digunakan untuk maksud ini.

$$
\begin{aligned}
& \text { Pengujian signifikansi } \\
& \text { dilakukan dengan } \\
& \text { membandingkan nilai t- } \\
& \text { statistik atau t-hitung dengan } \\
& \text { t-tabel pada level signifikansi } \\
& 10 \%, 5 \% \text {, dan 1\%. Jika nilai } \\
& \text { t-hitung > t-tabel maka dapat }
\end{aligned}
$$

disimpulkan bahwa abnormal return pada tanggal $\mathrm{t}$ signifikan secara statistik, yang berarti investor bereaksi positif terhadap pengumuman peningkatan peringkat (upgrade) dan bereaksi negatif terhadap pengumuman penurunan peringkat (downgrade) obligasi. Sedangkan jika nilai t-hitung < t-tabel maka dapat disimpulkan bahwa abnormal return pada tanggal t tidak signifikan secara statistik, yang berarti investor tidak bereaksi positif terhadap pengumuman peningkatan peringkat (upgrade) dan tidak bereaksi negatif terhadap pengumuman penurunan peringkat (downgrade) obligasi.

8. Uji perbedaan

Pengujian ini dilakukan untuk menguji hipotesis ketiga (H3) yaitu melihat apakah reaksi investor terhadap pengumuman perubahan peringkat obligasi perusahaan domestik lebih tinggi dibandingkan pengumuman perubahan peringkat obligasi perusahaan asing. Data diolah dengan menggunakan independent sampel t-test, yaitu dengan menggunakan program IBM SPSS 20. Uji ini digunakan untuk membandingkan dua kelompok mean sampel yang tidak berhubungan atau berbeda (independent).

Keputusan apakah hipotesis ditolak atau diterima didasarkan pada perbandingan antara t-hitung 


dengan t-tabel dan
probabilitas dengan level
signifikansi $10 \%, 5 \%$, dan
$1 \%$. Hipotesis diterima, jika t
hitung $>$ tabel atau
probabilitas $<\alpha$, hal ini
berarti reaksi investor
terhadap pengumuman
perubahan peringkat obligasi
perusahaan domestik lebih
tinggi dibandingkan
pengumuman perubahan
peringkat obligasi perusahaan
asing. Sedangkan, hipotesis
ditolak jika thitung $<$ tabel
atau probabilitas $>$, berarti
reaksi investor terhadap
pengumuman perubahan
peringkat obligasi perusahaan
domestik tidak lebih tinggi
dibandingkan pengumuman
perubahan peringkat obligasi
perusahaan asing.

\section{HASIL DAN PEMBAHASAN}

Pengujian hipotesis dalam penelitian ini akan dilakukan dengan metode event study. Metode ini digunakan untuk menguji hipotesis yang akan dilakukan secara bertahap. Tahap pertama menguji hipotesis pertama $\left(\mathrm{H}_{1 \mathrm{a}}\right.$ dan $\left.\mathrm{H}_{1 \mathrm{~b}}\right)$, yaitu menguji apakah investor bereaksi terhadap pengumuman perubahan peringkat obligasi perusahaan asing. Tahap kedua menguji hipotesis kedua $\left(\mathrm{H}_{2 \mathrm{a}}\right.$ dan $\mathrm{H}_{2 \mathrm{~b}}$ ), yaitu menguji apakah investor bereaksi terhadap pengumuman perubahan peringkat obligasi perusahaan domestik. Pengujian hipotesis pertama dan kedua akan dilakukan dengan membuktikan apakah terdapat abnormal return yang signifikan secara statistik (berbeda dengan nol) atau tidak. Tahap terakhir, menguji hipotesis ketiga (H3) tentang reaksi investor terhadap pengumuman perubahan peringkat obligasi perusahaan domestik lebih tinggi dibandingkan terhadap pengumuman perubahan peringkat obligasi perusahaan asing.

Pengujian hipotesis pertama dan kedua $\left(\mathrm{H}_{1 \mathrm{a}}, \mathrm{H}_{1 \mathrm{~b}}, \mathrm{H}_{2 \mathrm{a}}\right.$ dan $\left.\mathrm{H}_{2 \mathrm{~b}}\right)$ dilakukan dengan membentuk model expected return terlebih dahulu. Expected return untuk setiap perusahaan yang mengalami perubahan peringkat obligasi dilakukan dengan menggunakan market model. Pembentukan model ini dilakukan dalam tahapan time series dan menggunakan periode estimasi dari hari ke 110 sampai hari ke 11 sebelum pengumuman perubahan peringkat obligasi (-110, 11).

Sebelum dilakukan pemodelan, secara parsial return pasar diregresikan dengan return saham dengan menggunakan regresi sederhana (OLS). Dari hasil regresi, diperoleh koefisien $\alpha$ (alfa) dan $\beta$ (beta). Nilai (koefisien) tersebut akan digunakan untuk membentuk model expected return. Namun, beta saham yang dihasilkan dari regresi tersebut merupakan beta saham yang belum dikoreksi. Oleh sebab itu, akan dilakukan koreksi terhadap beta saham dengan menggunakan metode koreksi Fowler \& Rorke dengan tiga periode mundur (lag time) dan tiga periode maju (lead time). Periode tiga lag dan lead ini dipilih karena merupakan periode koreksi bias beta yang paling mampu mengurangi bias beta sesuai dengan data yang dimiliki (Ariff \& Johnson, 1990). Hasil perhitungan beta saham-saham terkoreksi yang diuji dalam penelitian ini bisa dilihat dalam Tabel 1 berikut: 
Tabel 1. Koreksi Beta dengan Metode Fowler \& Rorke

\begin{tabular}{|c|c|c|}
\hline Jumlah Lag/ Lead & OLS $\boldsymbol{\beta}$ & FR $\boldsymbol{\beta}$ \\
\hline 1 & 0,312 & 0,675 \\
\hline 2 & & 1,417 \\
\hline 3 & & 1,150 \\
\hline 4 & & 1,918 \\
\hline
\end{tabular}

Sumber: Data diolah

Beta pasar yang belum dikoreksi merupakan beta yang bias karena terjadinya perdagangan yang tidak sinkron. Beta yang bias ini ditunjukkan oleh nilai OLS $\beta$ yang lebih kecil dari satu (beta pasar seharusnya bernilai 1 ). Tabel 1 di atas menunjukkan rata-rata beta yang telah dikoreksi dengan metode koreksi Fowler \& Rorke dengan periode satu lag dan satu lead, periode dua lag dan dua lead, periode tiga lag dan tiga lead, dan periode empat lag dan empat lead. Rata-rata beta yang diperoleh dengan metode tersebut adalah sebesar 0,675 untuk periode satu lag dan satu lead, 1,417 untuk periode dua lag dan dua lead, 1,150 untuk periode tiga lag dan tiga lead, dan 1,918 untuk periode empat lag dan empat lead. Hal ini berarti bahwa pada periode tersebut saham-saham memiliki rata-rata beta yang lebih kecil dan besar (mendekati dan menjauhi beta pasar).

Beta saham secara keseluruhan atau disebut juga sebagai beta pasar merupakan nilai rata-rata tertimbang masing-masing beta saham individual. Dalam penelitian ini, beta pasar ditunjukkan oleh nilai rata-rata beta saham individual yang telah terkoreksi. Beta saham yang telah terhindar dari bias akibat perdagangan yang tidak sinkron diindikasikan oleh nilai rata-rata saham yang mendekati nilai 1,0
(Ariff \& Johnson, 1990; Tandelilin \& Wayan, 2001). Hasil koreksi beta saham seperti dalam Tabel 1 di atas menunjukkan bahwa metode yang paling mampu mengurangi bias beta saham adalah metode koreksi Fowler \& Rorke periode tiga lag dan tiga lead. Hasil ini konsisten dengan hasil penelitian Ariff \& Johnson (1990).

Setelah nilai $\alpha$ dan $\beta$ diperoleh, langkah selanjutnya adalah membentuk model expected return. Adapun nilai $\alpha$ merupakan nilai konstanta yang diperoleh dari hasil regresi antara return pasar dengan return saham selama periode estimasi $(-110,-11)$. Sedangkan nilai $\beta$ merupakan nilai yang diperoleh dari koreksi beta dengan menggunakan metode Fowler \& Rorke selama periode jendela yaitu, 10 hari sebelum sampai dengan 10 hari sesudah pengumuman perubahan peringkat obligasi ($10,+10)$. Setelah model expected return yang diperoleh, maka bisa dihitung nilai abnormal return dari tiap-tiap perusahaan yang mengalami perubahan peringkat obligasi. Abnormal return yang dihitung adalah abnormal return pada event window $(-10,+10)$. Setelah abnormal return diperoleh maka langkah selanjutnya adalah menghitung ratarata abnormal return selama event window tersebut.

\section{Pengujian reaksi investor terhadap pengumuman}


peringkat obligasi perusahaan asing

Tabel 2. Uji Signifikansi Hipotesis 1 dan 2 untuk Abnormal Return Perusahaan Asing dan Domestik yang mengalami Perubahan Peringkat Obligasi

\begin{tabular}{|c|c|c|c|c|c|c|c|c|}
\hline \multirow{3}{*}{ Periode } & \multicolumn{4}{|c|}{ Perusahaan Asing } & \multicolumn{4}{|c|}{ Perusahaan Domestik } \\
\hline & \multicolumn{2}{|c|}{ Upgrade } & \multicolumn{2}{|c|}{ Downgrade } & \multicolumn{2}{|c|}{ Upgrade } & \multicolumn{2}{|c|}{ Downgrade } \\
\hline & AAR & t hitung & AAR & t hitung & AAR & t hitung & AAR & t hitung \\
\hline-10 & 0,258 & $1,846^{*}$ & $-0,757$ & $-2,003 * *$ & $-0,412$ & $-1,597$ & $-0,343$ & $-1,373$ \\
\hline-9 & 0,121 & 0,861 & $-0,660$ & $-1,745^{*}$ & 0,091 & 0,353 & $-0,605$ & $-2,420 * *$ \\
\hline-8 & $-0,179$ & $-1,278$ & $-0,398$ & $-1,054$ & 0,471 & $1,825^{*}$ & 0,078 & 0,312 \\
\hline-7 & 0,105 & 0,753 & $-0,241$ & $-0,637$ & 0,733 & $2,838 * * *$ & 0,044 & 0,176 \\
\hline-6 & 0,381 & $2,722 * * *$ & $-0,517$ & $-1,368$ & 0,184 & 0,712 & $-0,217$ & $-0,867$ \\
\hline-5 & $-0,037$ & $-0,264$ & 0,392 & 1,037 & 0,759 & $2,939 * * *$ & $-0,435$ & $-1,741 *$ \\
\hline-4 & 0,083 & 0,591 & $-0,059$ & $-0,156$ & 0,281 & 1,090 & 0,370 & 1,482 \\
\hline-3 & $-0,132$ & $-0,939$ & 0,028 & 0,074 & 0,156 & 0,603 & 0,078 & 0,311 \\
\hline-2 & 0,195 & 1,389 & $-0,254$ & $-0,672$ & $-0,117$ & $-0,454$ & $-0,350$ & $-1,399$ \\
\hline-1 & $-0,156$ & $-1,111$ & 0,419 & 1,107 & 0,283 & 1,095 & $-0,136$ & $-0,543$ \\
\hline 0 & 0,341 & $2,435 * *$ & $-0,403$ & $-1,066$ & 0,619 & $2,396 * *$ & $-0,104$ & $-0,417$ \\
\hline 1 & 0,086 & 0,618 & 0,168 & 0,444 & $-0,375$ & $-1,454$ & 0,147 & 0,587 \\
\hline 2 & 0,029 & 0,209 & $-1,129$ & $-2,986 * * *$ & 0,132 & 0,511 & $-0,300$ & $-1,200$ \\
\hline 3 & 0,232 & 1,657 & $-0,365$ & $-0,965$ & $-0,128$ & $-0,494$ & 0,013 & 0,054 \\
\hline 4 & 0,314 & $2,243 * *$ & $-0,199$ & $-0,526$ & 0,066 & 0,255 & $-0,297$ & $-1,186$ \\
\hline 5 & 0,244 & $1,740 *$ & $-0,762$ & $-2,016^{* *}$ & 0,365 & 1,414 & $-0,391$ & $-1,562$ \\
\hline 6 & 0,401 & $2,867 * * *$ & 0,526 & 1,391 & 0,613 & $2,374 * *$ & 0,137 & 0,549 \\
\hline 7 & $-0,041$ & $-0,293$ & 0,155 & 0,410 & 0,089 & 0,344 & $-0,116$ & $-0,463$ \\
\hline 8 & 0,148 & 1,054 & $-0,238$ & $-0,629$ & 0,188 & 0,728 & $-0,354$ & $-1,415$ \\
\hline 9 & 0,123 & 0,876 & 0,418 & 1,105 & $-0,366$ & $-1,419$ & $-0,851$ & $-3,404 * * *$ \\
\hline 10 & 0,170 & 1,216 & $-0,294$ & $-0,778$ & 0,196 & 0,760 & $-0,582$ & $-2,327 * *$ \\
\hline
\end{tabular}

Keterangan:

*** Signifikan pada level $1 \%$

** Signifikan pada level $5 \%$

*Signifikan pada level 10\%

Pada periode sebelum pengumuman peningkatan peringkat obligasi (upgrade) perusahaan asing $(-10,0)$ hanya pada periode ke 10 dan 6 saja yang signifikan dan memiliki AAR positif. Sedangkan pada periode sebelum pengumuman penurunan peringkat obligasi (downgrade) perusahaan asing (10,0) hanya pada periode ke 10 dan 9 saja yang signifikan dan memiliki AAR negatif. Hal ini mengindikasikan bahwa terjadi kebocoran informasi sebelum pengumuman tersebut dipublikasikan ke publik.

Pada periode sebelum pengumuman peningkatan peringkat obligasi (upgrade) perusahaan domestik $(-10,0)$ hanya pada periode ke 8,7 dan 6 saja yang signifikan dan memiliki AAR positif. Sedangkan pada periode sebelum pengumuman penurunan peringkat obligasi (downgrade) perusahaan domestik $(-10,0)$ hanya pada periode 
ke 9 dan 5 saja yang signifikan dan memiliki AAR negatif. Hal ini mengindikasikan bahwa terjadi kebocoran informasi sebelum pengumuman tersebut dipublikasikan ke publik.
Pengujian perbedaan reaksi
investor terhadap pengumuman
perubahan peringkat obligasi
perusahaan asing dengan domestik

Tabel 3. Uji Signifikansi Perbandingan (Independent Sample t-Test) Average abnormal Return Perusahaan Asing dengan Domestik yang Mengalami Perubahan Peringkat Obligasi

\begin{tabular}{|c|c|c|c|c|c|c|c|c|}
\hline \multirow{2}{*}{ Periode } & \multicolumn{4}{|c|}{ Uji Beda (Upgrade) } & \multicolumn{4}{|c|}{ Uji Beda (Downgrade) } \\
\hline & $\mathbf{A} \mathbf{A} \mathbf{R}_{\mathbf{F U}}$ & $\mathbf{A} \mathbf{A} \mathbf{R}_{\mathrm{DU}}$ & t-stat & Prob & $\mathbf{A} \mathbf{A} \mathbf{R}_{\mathbf{F D}}$ & $\mathbf{A} \mathbf{A} \mathbf{R}_{\mathrm{DD}}$ & t-stat & Prob \\
\hline-10 & 0,258 & $-0,412$ & 1,666 & 0,101 & $-0,757$ & $-0,343$ & $-0,798$ & 0,434 \\
\hline-9 & 0,121 & 0,091 & 0,100 & 0,920 & $-0,660$ & $-0,605$ & $-0,102$ & 0,920 \\
\hline-8 & $-0,179$ & 0,471 & $-2,563$ & 0,013 & $-0,398$ & 0,078 & $-0,636$ & 0,531 \\
\hline-7 & 0,105 & 0,733 & $-1,496$ & 0,140 & $-0,241$ & 0,044 & $-0,706$ & 0,488 \\
\hline-6 & 0,381 & 0,184 & 0,598 & 0,552 & $-0,517$ & $-0,217$ & $-0,701$ & 0,491 \\
\hline-5 & $-0,037$ & 0,759 & $-2,276$ & 0,007 & 0,392 & $-0,435$ & 2,974 & 0,000 \\
\hline-4 & 0,083 & 0,281 & $-0,450$ & 0,665 & $-0,059$ & 0,370 & $-0,830$ & 0,416 \\
\hline-3 & $-0,132$ & 0,156 & $-0,827$ & 0,411 & 0,028 & 0,078 & $-0,093$ & 0,927 \\
\hline-2 & 0,195 & $-0,117$ & 0,970 & 0,336 & $-0,254$ & $-0,350$ & 0,184 & 0,856 \\
\hline-1 & $-0,156$ & 0,283 & $-1,394$ & 0,168 & 0,419 & $-0,136$ & 1,761 & 0,093 \\
\hline 0 & 0,341 & 0,619 & $-2,654$ & 0,000 & $-0,403$ & $-0,104$ & $-0,617$ & 0,544 \\
\hline 1 & 0,086 & $-0,375$ & 1,554 & 0,125 & 0,168 & 0,147 & 0,060 & 0,952 \\
\hline 2 & 0,029 & 0,132 & $-0,298$ & 0,767 & $-1,129$ & $-0,300$ & $-1,838$ & 0,080 \\
\hline 3 & 0,232 & $-0,128$ & 1,113 & 0,270 & $-0,365$ & 0,013 & $-1,568$ & 0,132 \\
\hline 4 & 0,314 & 0,066 & 0,820 & 0,415 & $-0,199$ & $-0,297$ & 0,288 & 0,776 \\
\hline 5 & 0,244 & 0,365 & $-0,372$ & 0,711 & $-0,762$ & $-0,391$ & $-0,852$ & 0,404 \\
\hline 6 & 0,401 & 0,613 & $-0,560$ & 0,577 & 0,526 & 0,137 & 0,774 & 0,448 \\
\hline 7 & $-0,041$ & 0,089 & $-0,433$ & 0,666 & 0,155 & $-0,116$ & 1,453 & 0,161 \\
\hline 8 & 0,148 & 0,188 & $-0,166$ & 0,869 & $-0,238$ & $-0,354$ & 0,238 & 0,815 \\
\hline 9 & 0,123 & $-0,366$ & 1,733 & 0,088 & 0,418 & $-0,851$ & 1,797 & 0,087 \\
\hline 10 & 0,170 & 0,196 & $-2,870$ & 0,000 & $-0,294$ & $-0,582$ & 0,554 & 0,586 \\
\hline
\end{tabular}

Keterangan:

FU adalah perusahaan asing yang mengalami peningkatan peringkat obligasi, DU adalah perusahaan domestik yang mengalami peningkatan peringkat obligasi, FD adalah perusahaan asing yang mengalami penurunan peringkat obligasi, dan DD adalah perusahaan domestik yang mengalami penurunan peringkat obligasi.

Untuk periode sesudah pengumuman peningkatan peringkat obligasi (upgrade) perusahaan domestik $(0,+10)$ hanya pada periode ke 0 dan 6 saja yang signifikan dan memiliki AAR positif. Sedangkan pada periode sesudah pengumuman penurunan peringkat obligasi (downgrade) perusahaan domestik $(0,+10)$ hanya pada periode ke 9 dan 10 saja yang signifikan dan memiliki AAR negatif. Terdapatnya AAR positif disekitar pengumuman peningkatan peringkat obligasi 
(periode $-8,-7,-6, \quad 0$, dan +6 ) menunjukkan bahwa investor bereaksi positif terhadap pengumuman peningkatan peringkat obligasi perusahaan domestik. Sedangkan terdapatnya AAR negatif di sekitar pengumuman penurunan peringkat obligasi (periode $-9,-5,+9$, dan +10) menunjukkan bahwa investor bereaksi negatif terhadap pengumuman penurunan peringkat obligasi perusahaan domestik. Dengan terdapat reaksi investor terhadap pengumuman perubahan (peningkatan dan penurunan) peringkat obligasi perusahaan domestik, maka dapat disimpulkan bahwa hipotesis kedua juga terdukung $\left(\mathbf{H}_{2 \mathrm{a}}\right.$ dan $\mathbf{H}_{2 \mathrm{~b}}$, diterima).

Hipotesis ketiga dilakukan untuk menguji apakah reaksi investor terhadap pengumuman peningkatan (penurunan) peringkat obligasi perusahaan domestik lebih tinggi dibandingkan terhadap pengumuman peningkatan (penurunan) peringkat obligasi perusahaan asing. Uji signifikansi perbandingan dilakukan terhadap rata-rata dua sampel (AAR) yang tidak berhubungan. AAR perusahaan asing yang mengalami perubahan (peningkatan \& penurunan) peringkat obligasi dibandingkan dengan AAR perusahaan domestik yang mengalami perubahan (peningkatan $\&$ penurunan) peringkat obligasi.

Untuk periode sebelum pengumuman peningkatan peringkat obligasi (upgrade) $(-10,0)$ hanya pada periode ke 8 dan 5 saja yang berbeda secara signifikan (t-hitung $>$ t-tabel). Sedangkan untuk periode sesudah pengumuman peningkatan peringkat obligasi (upgrade) $(0,+10)$ hanya pada periode ke 0,9 dan 10 saja yang berbeda secara signifikan (t-hitung $>$ t-tabel atau prob $<\alpha$ ), dimana AAR perusahaan domestik lebih besar AAR perusahaan asing $\left(A_{A} R_{D U}>A_{A A R}\right)$. Signifikannya perbandingan antara AAR perusahaan asing dengan AAR perusahaan domestik yang mengalami peningkatan peringkat obligasi (upgrade) sekitar tanggal pengumuman, menunjukkan bahwa reaksi investor terhadap pengumuman peningkatan peringkat obligasi perusahaan domestik lebih tinggi dibandingkan terhadap pengumuman peningkatan peringkat obligasi perusahaan asing.

Sedangkan untuk periode sebelum pengumuman penurunan peringkat obligasi (downgrade) (10,0) hanya pada periode ke 5 dan 1 saja yang berbeda secara signifikan (t-hitung > t-tabel). Sedangkan untuk periode sesudah pengumuman penurunan peringkat obligasi (downgrade) $(0,+10)$ hanya pada periode ke 2 dan 9 saja yang berbeda secara signifikan (t-hitung > t-tabel atau prob $<\alpha$ ), dimana AAR perusahaan domestik lebih kecil AAR perusahaan asing $\left(\mathrm{AAR}_{\mathrm{DU}}<\right.$ $\mathrm{AAR}_{\mathrm{FU}}$ ). Signifikannya perbandingan antara AAR perusahaan asing dengan AAR perusahaan domestik yang mengalami penurunan peringkat obligasi (downgrade) sekitar tanggal pengumuman, menunjukkan bahwa reaksi investor terhadap pengumuman penurunan peringkat obligasi perusahaan domestik juga lebih tinggi dibandingkan terhadap pengumuman penurunan peringkat obligasi perusahaan asing. Hasil pengujian hipotesis ketiga (H3) menunjukkan bahwa reaksi investor terhadap pengumuman peningkatan (penurunan) peringkat obligasi 
perusahaan domestik lebih tinggi dibandingkan terhadap pengumuman peningkatan (penurunan) peringkat obligasi perusahaan asing. Dengan demikian $\mathrm{H}_{0}$ ditolak, $\mathbf{H}_{3}$ diterima.

\section{SIMPULAN DAN IMPLIKASI PENELITIAN}

Hasil penelitian 89 observasi yang terdiri dari perusahaan asing dan domestik menunjukkan bahwa investor bereaksi terhadap pengumuman peningkatan (upgrade) dan penurunan (downgrade) peringkat obligasi perusahaan asing maupun domestik. Hasil ini ditunjukkan oleh terdapatnya abnormal return positif yang signifikan di sekitar pengumuman peningkatan peringkat obligasi dan abnormal return negatif yang signifikan di sekitar pengumuman penurunan peringkat obligasi perusahaan asing dan domestik. Hal ini mengindikasikan bahwa pasar modal Indonesia memiliki reaksi yang signifikan terhadap pengumuman peningkatan (upgrade) dan penurunan (downgrade) peringkat obligasi (Andriansyah,2002; Zuhrotun, 2005; Ariyanti, 2008).

Selain itu, juga ditemukan adanya perbedaan reaksi investor terhadap pengumuman perubahan peringkat obligasi perusahaan asing dan perusahaan domestik. Dimana reaksi investor terhadap pengumuman peningkatan (penurunan) peringkat obligasi

\section{DAFTAR PUSTAKA}

Andriansyah. (2002). The Effect of Bond Rating Change Announcements on Stock perusahaan domestik lebih tinggi dibandingkan terhadap pengumuman peningkatan (penurunan) peringkat obligasi perusahaan asing. Temuan ini konsisten dengan temuan sebelumnya, yaitu penelitian Dvorak (2005) yang menunjukkan bahwa reaksi investor domestik lebih tinggi dibandingkan dengan investor asing. Perusahaan asing yang didominasi oleh investor asing memiliki informasi yang lebih baik tentang faktor-faktor fundamental yang berkaitan dengan ekuitas daripada perusahaan domestik yang didominasi investor domestik (Seasholes, 2000; Froot \& Ramadorai, 2001).

Hasil penelitian ini membawa implikasi pada studi-studi empiris terdahulu dan praktik dengan adanya perubahan (peningkatan dan penurunan) peringkat obligasi kategori perusahaan asing dan domestik. Secara keseluruhan, penelitian ini menunjukkan bahwa perubahan peringkat obligasi memiliki informasi yang diserap oleh pasar. Dalam arti kata, investor bereaksi positif terhadap pengumuman peningkatan peringkat (upgrade) obligasi dan bereaksi negatif terhadap penurunan peringkat (downgrade) obligasi, baik untuk kategori perusahaan asing maupun domestik. Hal ini dapat terjadi karena perubahan peringkat yang dialami oleh perusahaan merupakan informasi yang relevan dengan profitabilitas perusahaan.
Prices; An Empirical Examination in Indonesia Stock Market. Tesis S-2 MM UGM. 
Anna, P. (2008).Pemilihan Rasio Keuangan Terbaik Untuk Memprediksi Peringkat Obligasi: Studi Pada Perusahaan Manufaktur yang Terdaftar di BEJ. Kinerja, Volume 12, No.1 : Hal. 8599.

Ariff, M., \& L. W. Johnson. (1990). Securities Markets \& Stock Pricing: Evidence From a Developing Capital Market in Asia. Longman Singapore Publisher Ltd, Singapore.

Ariyanti, N. (2008). Pengaruh Pengumuman Upgrade dan Downgrade Peringkat Obligasi terhadap Return Saham di Bursa Efek Jakarta.Tesis $\quad \mathrm{S}-2$ Pascasarjana UGM.

Basuki, O. (2012). Reaksi Harga Saham Terhadap Rekomendasi Saham yang di Publikasikan Harian Kontan dalam Rubrik "Rekomendasi". Tesis S-2 Pascasarjana UI.

Bhattacharya, U., Dauouk, H., Jorgenson, B., \& Kehr, C. H. (2000). When an Event id Not an Event: The Curious Case of an Emerging Market. Journal of Financial Economics, Vol. 55, pp. 69101.

Chae, J. (2005). Trading Volume, Information Asymmetry, and Timing Information. The Journal of Finance, Vol. 60, No. 1, Pp. 413-442.

Chandra, Rudy. (2010). Analisis Pemilihan Saham oleh Investor Asing di Bursa Efek
Indonesia. Bisnis \& Birokrasi, Jurnal Ilmu Administrasi dan Organisasi, hal. 101-113.

Choe, H., Chan, B. K., \& Stulz, R. M. (2001). Do Domestic Investors Have More Valuable Information about Individual Stocks than Foreign Investors?. NBER Working Paper, No. 8073.

Dichev, I. D. (1998). Is the Risk of Bankruptcy a Systematic Risk?. Journal of Finance 53(3), Pp. 1131-1147.

Dichev, I. D., \& Joseph D. P. (2001). The Long-Run Stock Returns Following Bond Rating Changes. Journal of Finance 56(1) Pp. 55-84.

Dorsey, W. (2003). Behavioral Trading: Methods for Measuring Investor Confidence and Expectation and Market Trends. Cencage Learning.

Dvorak, T. (2005). Do Domestic Investors Have an Information Advantage? Evidence from Indonesia. Journal of Finance, Vol. 25 (2), pp. 817-839.

Edi, B. S., \& Shanti. (2009). Reaksi Pasar Saham Terhadap Pengumuman Perubahan Peringkat Obligasi Perusahaan yang Terdaftar di Bursa Efek Jakarta. Modus Vol.21 (1): 73-86.

Errunza, V. R. (1986). On Benefits of Tapping Foreign Portfolio Investments: An Indian Perspective. Economic and 
Political Weekly, Vol. 21, No. 8.

Fabozzi, F. J. 2000.Bond Market Analys and Strategies. Prentice-Hall. Inc $4^{\text {th }}$ Edition.

Fang, L., \& Peress, J. (2009). Media Coverage and the Cross Section of StockReturns and Bonds. Journal of Financial Economic. 33 (1). Pp 2113 2127.

Froot, K. A., \& Ramadorai, T. (2001). The Information Content of International Portfolio Flows. NBER Working Paper, No. 8472.

Goh, J. C., \& Louis H. E. (1993). Is a Bond Rating Downgrade Bad News, Good News, or No News for Stockholders?. Journal of Finance, Vol. 48, No. 5, pp. 2001-2008.

Gropp, R., \& Anthony J. R. (2001). Rating Agency Actions and the Pricing of Debt and Equity of European Banks: What Can We Infer about Private Sector Monitoring of Bank Soundness?. Working Paper European Central Bank, pp. 1-35.

Hand, J. R. M., Robert W. H., \& Richard, W. L. (1992). The Effect of Bond Rating Agency Announcements on Bond and Stock Prices. Journal of Finance 47(2), Pp. 733-752.

Harsono, R. D. B. (2003). Perdagangan Berbasis Informasi dan Noise, Volume Transaksi Investor Asing dan Domestik dan Volatilitas
Pasar di BEJ Sejak Liberalisasi Pasar.Tesis S-2. Pascasarjana UGM.

Hartono, J. 2012.Teori Portofolio dan Analisis Investasi. Edisi Ketujuh. Yogyakarta. BPFE.

Holthausen, R., \& Richard, L. (1986). The effect of bond rating changes on common stock prices. Journal of Financial Economics 17, Pp. 57-89.

Husnan, S. (1994). Investasi Di Pasar Modal, Perkembangan, Kecenderungan, Kebutuhan dan Prospek. Kelola. No 7. III. Pp 100-113.

Ika, S., \& Singgih, R. (1996). Peranan Pasar Modal Indonesia dalam Memenuhi Target Investasi Repelita IV.Jurnal Keuangan dan Moneter, Vol. 3, No. 3, Hal. 72-97.

Kamstra, M., Peter, K., \& Teck, K. S. (2001). Combining Bond Rating Forecasts Using Logit.The Financial Review 37, pp. 75-96.

Kang, J., \& Stulz, R. (1997). Why is There Home Bias? An Analysis of Foreign Portfolio Equity Ownership in Japan. Journal of Financial Economics, Vol. 46, pp. 3-28.

Karyani, E., \& Adler, M. 2006. Pengaruh Pengumuman Perubahan Bond Rating terhadap Return Saham Perusahaan (Penelitian Periode 2003 s.d.2005).Jurnal Riset 
Akuntansi Indonesia.Vol : 9 hal : 282-306.

Kato, H. K., Uri, L., \& Wenyuh, T. (2002). Dividend Policy, Cash Flow, and Investment in Japan. Pasific-Basin Finance Journal 10, Pp. 443-473.

Kliger, D., \& Oded, S. (2000). The Information Value of Bond Ratings.Journal of Finance, Vol. 55, No. 6, pp. 28792902.

Raharja., \& Maylia. P. S. (2008). Kemampuan Rasio Keuangan dalam Memprediksi Peringkat Obligasi (PT Kasnic Credit Rating). Jurnal Maksi, Vol. 8, No. 2, pp. 212232.

Samsul, M. (2006). Pasar Modal dan Manajemen Portofolio. Jakarta: Erlangga.

Salomons, R., \& Grootveld, H. (2003). The Equity Risk Premium: Emerging Versus Developed Markets. Emerging Markets Review 4.

Scott, W. R. (2003). Financial Accounting Theory. Upper Saddle River, NJ: PrenticeHall, Inc.

Seasholes, M. S. (2000). Smart Foreign Traders in Emerging Markets. Working Paper. University of California at Barkeley.
Suwiryo, A. P. (2009). Reaksi Investor Asing dan Domestik terhadap kandungan Informasi Laba.Tesis S-2. Pascasarjana UGM.

Tandelilin, E. (2010). Portofolio dan Investasi: Teori dan Aplikasi. Yogyakarta: Kanisius Yogyakarta.

Tandelilin, E., \& I Wayan Nuka Lantara. (2001). Stabilitas dan Prediktabilitas Beta Saham: Studi Empiris di Bursa Efek Jakarta. Jurnal Ekonomi dan Bisnis Indonesia, Vol. 16, No.2, Hal. 164-176.

Wansley, J., \& Terrence, C. (1985). The impact of credit watch placement on equity returns and bond prices. Journal of Financial Research 8, Pp. 3142.

Zuhrotun. (2005). Pengaruh Pengumuman Peringkat terhadap Kinerja Obligasi. Tesis S-2 Akuntansi UGM. 